\title{
Prevalence and Antimicrobial susceptibility of Pathogenic Bacteria in Tilapia zilli and Mugil capito
}

\author{
Khafagy A. R.*, Essawy, A. E.**, \\ Noura H. Abou-El Moaty $* * *$ and Hala F. Ayoub**** \\ *Department of Bacteriology, Immunology and Mycology \\ Department, Faculty of Veterinary Medicine, Suez Canal \\ University. **Animal Health Research Institute. \\ *** Academic Researcher of Microbiology. **** Department \\ of Fish Health and Management, Central laboratory for \\ Aquaculture Research, Agricultural Research center (CLAR), \\ Abbassa, sharqia, Egypt.
}

\begin{abstract}
A total of 300 marine fishes of two different species represented as (150) tilapia Zilli and 150 mugil capito) were freshly collected randomly from the different markets in the Ismailia governorate, during different seasons. The samples were subjected to full clinical, postmortem, and bacteriological studies. The common clinical signs were darkness in the skin, hemorrhage in the base of fins, eyes \& different parts of the body, abdominal distention, congestion in gills, and increase in mucous secretion. The postmortem finding showed white serous fluid tinged with blood in the abdominal cavity and pale or congested liver, kidney, and spleen. The result indicated that the prevalence of bacterial pathogens among naturally infected marine fishes were Aeromonas hydrophila 91 isolates (39.39\%), $V$. alginolyticus 67 isolates (29\%), $P$. fluorescens 42 isolates (18.18\%), V. fluvialis 17 isolates (7.4\%), P.aeruginosa 14 $(6.06 \%)$. The result of the antibiogram revealed that Aeromonas hydrophila is highly sensitive to ciprofloxacin, while ciprofloxacin and rifampicin are more effective against $P$. fluorescence, also ciprofloxacin and amikacin against $P$. aeruginosa, while $V$. alginolyticus was highly sensitive to oxytetracycline and rifampicin. Ciprofloxacin and naldixic acid more effective against $V$. fluvialis
\end{abstract}

Key words: Tilapia zilli, Mugil capito, Aeromonas spp, Sensitivity test 


\section{Introduction}

Bacteria play the main role in producing the disease in fish although incidence of bacterial diseases in fish generally do not develop simply as the result of exposing a host to an infectious agent Wedekind et al. (2010). Moreover, bacterial fish disease is a major problem facing fish farming industry, which is currently fast through a variety of growing with annual increase approximately $12 \% . \quad \boldsymbol{F A O}$ (2004).

The normal bacterial flora of fish is direct reflection of bacterial population water in which they swim and bacterial infections such as Vibriosis, Aeromonads, Pseudomonads, Photobacteria, Streptococci and Staphylococci were recorded in several fingerlings, juveniles, adults and brood stocks of some marine fish species (Toranzo et al., 2005). The prevalence of bacterial pathogens have been well documented in several cultured and wild fresh water fish species, however; only a few bacteriological surveys on the prevalence of bacterial pathogens responsible for outbreaks in marine fish, it is important to point out that diseases classically considered as typical of fresh water aquaculture, such as furunculosis (Aeromonas salmonicida), bacterial kidney disease (BKD) (Renibacterium salmoninarum) and some types of streptococcosis, are today important problems also in marine culture (Toranzo et al., 2005)

Fish diseases are the result of the interaction among pathogen, host and environment. Consequently, multidisciplinary studies involving the virulence factors of the pathogenic microorganisms, aspects of the biology and immunology of the fish, as well as a better understanding of the environmental conditions affecting fish cultures, will allow the application of adequate measures to control and prevent the microbial diseases limiting the production of marine fishes. Salah et al. (2012).

Therefore, the current investigation aimed to isolation and identification of bacterial pathogens from naturally infected marine fishes (Tilapia zilli and Mugil capito) with special reference to the best effective antibiotics for controlling the infection.

\section{Material and methods sampling:}

A total of 300 marine fishes of two different spp. represented as (150 T.zilli and 150 M.capito) were freshly collected randomly from different markets in Suez Canal area, Ismailia governorate 
during different seasons (from January 2019 to December 2019). In a rate 37 fish of each species were collected and examined seasonally, Clinical and post mortem examination were carried out using the methods described by Hudzicki (2009).

Isolation of suspected bacteria

Samples from kidney liver, gills and spleen from examined fishes were cultured in general and selective media; tryptic soy broth, tryptic soy agar (Oxoid) supplemented with $2 \% \mathrm{NaCl}$ (w/v), thiosulphate citrate bile salt agar (Oxoid), aeromonas base media supplemented with ampicillin and pseudomonas agar base media supplemented with $2 \% \quad \mathrm{NaCl} \quad(\mathrm{w} / \mathrm{v})$ and glycerin 2\%. All inoculated media were incubated at $28^{\circ} \mathrm{C}$ for 1- 2 days.

Identification of the isolated bacteria

Pure cultures of isolated bacteria were identified biochemically according to (Brenner et al., 2005) and final confirmation of bacterial isolates was achieved by using the analytical profile index of API20E system (Buller, 2004). Antibiogram sensitivity test This test was done following Hudzicki (2009) by using the disc diffusion method on Muller's Hinton agar medium and the following discs Oxytetracycline, Ampicillin, Amoxycillin,

Lincomycin, Ciprofloxacin,

Colistin sulphate, Nalidixic acid, Amikacin, Rifampcine and Erythromycin were kindly recorded. Susceptibility was defined as absence of growth on solid medium containing any of these antimicrobial agents. Presence of growth indicated nonsusceptibility. The diameters of the inhibition zone appearing on the agar plate were measured and interpreted as susceptible (S), intermediate (I) or resistant (R).

\section{Results}

\section{Clinical examination:}

The examined fish showed darkness of external body surface, opacity of eye, increased in mucous secretion, exophthalmia and some fishes showed hemorrhage in eye, scales detachment and large irregular hemorrhagic areas into many parts of the body, in some cases, the gills were congested while in others appeared pale in color and swollen photo (1\&2).

\section{Postmortem examination}

The examined fish showed white serous fluid in abdominal cavity, some tinged with blood. The liver surface and in some cases appeared congested while in some fish appeared to be normal with normal texture. 
kidney congested and slightly enlarged. The intestine of some cases appeared normal. In some fish appeared hemorrhagic areas in the abdominal wall \& on peritoneum and some fishes apparently healthy without any internal or external lesions.as shown in photo (3).

\section{Bacteriological examination:}

The result indicated that 150 naturally infected and 150 apparently healthy marine fishes were found to be infected with different types of bacteria.The samples were taken from liver, kidney, spleen, gills. The result demonstrated that the total number of bacterial isolates from (300) fish (69) isolate were negative with percentage of $(23 \%)$ and 231 isolates were positive with percentage of (77\%) from which 103 isolates from M.capito and 128 isolates belonging to T.zilli fish as shown in table (3), from the isolates there were $22(14.29 \%)$ were oxidase positive bacterial isolates, Aeromonas (the most common bacterial pathogens) 158 (68.4\%) (A. hydrophila 91(39.39),V. alginolyticus 67 (29\%) , P. fluorescens 42(18.2\%), P. aeruginosa 14 (6.1\%), V. fluvialis $17(7.4 \%)$ as shown in table (1).

the bacteriological examination revealed that the identification of 91 (39.39\%) of A. hydrophila and the identification of 42 (18.2\%) of P. fluorescens and
$14(6.1 \%)$ of $P$. aeruginosa and $V$. fluvialis isolates were identified as $17 \quad(7.4 \%)$ depending on different tests applied to demonstrate the culture and biochemical characters as present in table (1). Concerning the seasons, the highest prevalence of bacterial infection recorded in summer season $(33.33 \%)$ followed by spring $(24.42 \%)$, then autumn (21.97\%), while minimal prevalence recorded in winter season $(20.46 \%)$ as recorded in table (4) and figure (1).

Concerning the organs, the highest prevalence of $A$. hydrophila was recorded in liver $(44.23 \%)$, followed by the kidney (36.54\%) then spleen $(11.54 \%)$. While the lowest prevalence recorded in gills (7.69\%) and the highest prevalence of Ps. fluorescens was recorded in kidney (50\%), followed by liver (25\%), then gills $(16.67 \%)$. While minimal prevalence was recorded in spleen (8. 33\%). while the highest prevalence of $P$. aeruginosa was recorded in liver and kidney with the same percent $(37.5 \%)$ and the minimal prevalence was recorded also equally in spleen and gills (12.5\%). and the highest prevalence of $V$. alginolyticus was recorded in liver $(36.84 \%)$, then kidney (31.58\%), then spleen (23.68\%). While the lowest prevalence 
recorded in gills (7.89\%) and the highest prevalence of $V$. fluvialis recorded in kidney (40\%), then spleen (30\%), followed by liver $(20 \%)$. While the lowest prevalence was recorded in gills (10\%) as shown in table (5) and figure (2).

\section{Antibiogram sesitivity test}

The result of antibiogram sesitivity test revealed that ciprofloxacin was more effective against Aeromonas hydrophila while ciprofloxacin and rifampicine more effective against Pseudomonas fluorescens, also ciprofloxacin and amikacin against $P$. aeruginosa, while $V$. alginolyticus was highly sensitive to rifampicine. Ciprofloxacin and naladixic acid more effective against $V$. fluvialis as shown in table (6).

Table (1): The biochemical and morphological characters of isolated bacteria from examined marine fishes (T.zilli \&M.capito)

\begin{tabular}{|c|c|c|c|c|c|}
\hline & $\begin{array}{l}\text { A. hydrop } \\
\text { hila. }\end{array}$ & $\begin{array}{l}\text { P. fluoresc } \\
\text { ens. }\end{array}$ & $\begin{array}{l}\text { P. aerugin } \\
\text { osa. }\end{array}$ & $\begin{array}{l}\text { V. alginolyti } \\
\text { cus. }\end{array}$ & $\begin{array}{l}\text { V. fluvi } \\
\text { alis }\end{array}$ \\
\hline 1. Gram stain. & - & - & - & - & - \\
\hline 1. Shape. & Short rod. & Short rod & Short rod & $\begin{array}{c}\text { Comma } \\
\text { shape bacilli }\end{array}$ & $\begin{array}{l}\text { Curved } \\
\text { cell }\end{array}$ \\
\hline 2. Motility. & + & + & + & + & + \\
\hline 3. Cytochrome oxidase. (Ox). & + & + & + & + & + \\
\hline 4. Catalase Test. & + & + & + & + & + \\
\hline $\begin{array}{l}\text { 5. B-Galactosidase } \\
\text { production (OPNG). }\end{array}$ & + & - & - & - & + \\
\hline $\begin{array}{l}\text { 6. Arginine } \\
\text { hydrolase production (ADH) }\end{array}$ & - & + & + & - & - \\
\hline $\begin{array}{l}\text { 7. Lysine decarboxylase } \\
\text { production (LDC). }\end{array}$ & - & + & - & + & - \\
\hline $\begin{array}{l}\text { 8.Ornithinedecarboxylase pr } \\
\text { oduction (ODC). }\end{array}$ & + & + & - & + & + \\
\hline 9. Citrate utilization (CIT) & - & + & + & - & - \\
\hline 10. $\mathrm{H}_{2} \mathrm{~S}$ production $\left(\mathrm{H}_{2} \mathrm{~S}\right)$. & - & - & - & - & - \\
\hline 11. Urease production (URE) & - & - & + & - & - \\
\hline $\begin{array}{l}\text { 12. Tryptophan deaminase } \\
\text { production (TDA). }\end{array}$ & - & - & - & - & - \\
\hline
\end{tabular}




\begin{tabular}{|l|c|c|c|c|c|}
\hline 13. Indole production (IND). & + & - & - & + & + \\
\hline 14. Acetoin production (VP). & - & - & + & - & + \\
\hline $\begin{array}{l}\text { 15. Gelatinase production } \\
\text { (GEL) }\end{array}$ & + & - & + & + & + \\
\hline 16. Acid from glucose & + & - & - & + & V \\
\hline 17. Acid from manitole. & + & - & - & + & + \\
\hline 18. Acid from inositol. & + & - & - & - & - \\
\hline 19. Acid from sorbitol & + & - & - & - & - \\
\hline 20. Acid from rhaminos. & - & - & - & - & - \\
\hline 21. Acid from sacrose & + & - & - & + & + \\
\hline 22. Acid from melobiose & - & - & - & - & - \\
\hline 23. Acid from amylase & + & - & - & - & - \\
\hline
\end{tabular}

Table (2) Prevalence of bacterial isolates recovered from examined marine fishes (T.zilli and M.capito) after oxidase +ve test

\begin{tabular}{|c|c|c|c|c|}
\hline A.hydrophila & $\boldsymbol{P}$. fluorescens & $\begin{array}{c}\boldsymbol{P} \text {. } \\
\text { aeruginosa }\end{array}$ & V. alginolyticus & V.fluvialis \\
\hline 91 & 42 & 14 & 67 & 17 \\
\hline 39.39 & 18.18 & 6.06 & 29 & 7.4 \\
\hline
\end{tabular}

Table (3) Prevalence of bacterial species isolated from examined M.capito and T.zilli

\begin{tabular}{|l|c|c|c|c|}
\hline \multirow{2}{*}{ Fish spp. } & \multicolumn{2}{c|}{ M.capito } & \multicolumn{2}{c|}{ T.zilli } \\
\cline { 2 - 5 } Bacterial spp. & No & \% & No & $\%$ \\
\hline A. hydrophila & 40 & 39 & 72 & 56 \\
\hline P. fluorescens & 14 & 13.55 & 26 & 20.55 \\
\hline P. aeruginosa & 12 & 11.86 & 0 & 0 \\
\hline V. alginolyticus & 7 & 6.77 & 23 & 17.80 \\
\hline V.fluvialis & 30 & 28.8 & 7 & 5.48 \\
\hline Total & $\mathbf{1 0 3}$ & $\mathbf{4 4 . 7 0}$ & $\mathbf{1 2 8}$ & $\mathbf{5 5 . 3 0}$ \\
\hline
\end{tabular}


Table (4) Seasonal prevalence of bacterial species in examined marine fishes

\begin{tabular}{|c|c|c|c|c|c|c|c|c|c|c|}
\hline Season. & \multicolumn{2}{|c|}{ Winter } & \multicolumn{2}{|c|}{ Spring } & \multicolumn{2}{|c|}{ Summer } & \multicolumn{2}{|c|}{ Autumn } & \multicolumn{2}{|c|}{ Total } \\
\hline Isolates. & No. & $\%$ & No. & $\%$ & No. & $\%$ & No. & $\%$ & No. & $\%$ \\
\hline A. hydrophila & 24 & 51.85 & 21 & 37.5 & 32 & 40.91 & 14 & 27.59 & 91 & 39.39 \\
\hline P.fluorescens & 14 & 29.63 & 14 & 25 & 0 & 0 & 14 & 27.59 & 42 & 18.18 \\
\hline P.aeruginosa & 0 & 0 & 7 & 12.5 & 7 & 9.090 & 0 & 0 & 14 & 6.06 \\
\hline V.alginolyticus & 9 & 18.52 & 12 & 21.88 & 28 & 36.36 & 18 & 34.48 & 67 & 29 \\
\hline V.fluvialis & 0 & 0 & 2 & 3.13 & 10 & 13.64 & 5 & 10.35 & 17 & 7.4 \\
\hline Total & 47 & 20.46 & 56 & 24.24 & 77 & 33.33 & 51 & 21.97 & 231 & 100 \\
\hline
\end{tabular}

Table (5) Incidence of bacterial species isolated from examined organs of marine fishes

\begin{tabular}{|l|c|c|c|c|c|c|c|c|c|c|c|c|}
\hline organ & \multirow{2}{*}{ A.hydropila } & \multicolumn{2}{|c|}{$\begin{array}{c}\boldsymbol{P} . \\
\text { fluorescens }\end{array}$} & \multicolumn{2}{|c|}{$\begin{array}{c}\text { P. } \\
\text { aeruginosa }\end{array}$} & \multicolumn{2}{|c|}{ V.alginolyticus } & \multicolumn{2}{|c|}{$\begin{array}{c}\text { V. } \\
\text { fluvialis }\end{array}$} & \multicolumn{2}{|c|}{ Total } \\
\hline & No. & $\%$ & No. & $\%$ & No. & $\%$ & No. & $\%$ & No. & $\%$ & No. & $\%$ \\
\hline Liver & 40 & 44.23 & 11 & 25 & 5 & 37.5 & 25 & 36.84 & 3 & 20 & 84 & 36.36 \\
\hline Kidney & 33 & 36.54 & 21 & 50 & 5 & 37.5 & 21 & 31.58 & 7 & 40 & 87 & 37.84 \\
\hline Spleen & 11 & 11.54 & 3 & 8.33 & 2 & 12.5 & 16 & 23.68 & 5 & 30 & 37 & 15.91 \\
\hline Gills & 7 & 7.69 & 7 & 16.67 & 2 & 12.5 & 5 & 7.89 & 2 & 10 & 23 & 9.85 \\
\hline Total & $\mathbf{9 1}$ & $\mathbf{3 9 . 3 9}$ & $\mathbf{4 2}$ & $\mathbf{1 8 . 1 8}$ & $\mathbf{1 4}$ & $\mathbf{6 . 0 6}$ & $\mathbf{6 7}$ & $\mathbf{2 9}$ & $\mathbf{1 7}$ & $\mathbf{7 . 4}$ & $\mathbf{2 3 1}$ & $\mathbf{1 0 0}$ \\
\hline
\end{tabular}

Table (6) Antibiogram of isolated bacterial species from examined marine fishes

\begin{tabular}{|l|c|c|c|c|c|c|c|c|}
\hline \multirow{2}{*}{ Antimicrobial disc } & \multicolumn{9}{|c|}{ Isolated strains. } \\
\cline { 2 - 10 } & \multicolumn{2}{|c|}{ A. hydrophila } & \multicolumn{2}{c|}{$\boldsymbol{P}$. fluorescens } & \multicolumn{2}{c|}{ P.aeruginosa } & \multicolumn{2}{c|}{ V.alginolyticus } \\
\cline { 2 - 10 } & $\begin{array}{c}\text { Inhb.z } \\
(\mathbf{m m})\end{array}$ & React. & $\begin{array}{c}\text { Inhb.z } \\
(\mathbf{m m})\end{array}$ & React. & $\begin{array}{c}\text { Inhb.z } \\
(\mathbf{m m})\end{array}$ & React. & $\begin{array}{c}\text { Inhb.z } \\
(\mathbf{m m})\end{array}$ & React. \\
\hline Ciprofloxacin & 27 & $\mathrm{~S}$ & 22 & $\mathrm{~S}$ & 30 & $\mathrm{~S}$ & 24 & $\mathrm{~S}$ \\
\hline Colistine sulfate & 7 & $\mathrm{R}$ & 10 & $\mathrm{M}$ & 10 & $\mathrm{M}$ & 10 & $\mathrm{M}$ \\
\hline Oxytetracycline & 22 & $\mathrm{~S}$ & 18 & $\mathrm{~S}$ & & $\mathrm{R}$ & 26 & $\mathrm{~S}$ \\
\hline Erythromycin & 16 & $\mathrm{M}$ & 16 & $\mathrm{R}$ & 12 & $\mathrm{R}$ & 15 & $\mathrm{R}$ \\
\hline Nalidixic acid & 23 & $\mathrm{~S}$ & 20 & $\mathrm{~S}$ & 12 & $\mathrm{R}$ & & $\mathrm{R}$ \\
\hline Amoxicillin & & $\mathrm{R}$ & 16 & $\mathrm{~S}$ & 12 & $\mathrm{M}$ & 12 & $\mathrm{R}$ \\
\hline Rifampicine & 15 & $\mathrm{R}$ & 21 & $\mathrm{~S}$ & 14 & $\mathrm{R}$ & 26 & $\mathrm{~S}$ \\
\hline Lincomycin & & $\mathrm{R}$ & & $\mathrm{R}$ & & $\mathrm{R}$ & & $\mathrm{R}$ \\
\hline Ampicillin & & $\mathrm{R}$ & 12 & $\mathrm{R}$ & & $\mathrm{R}$ & 12 & $\mathrm{R}$ \\
\hline
\end{tabular}




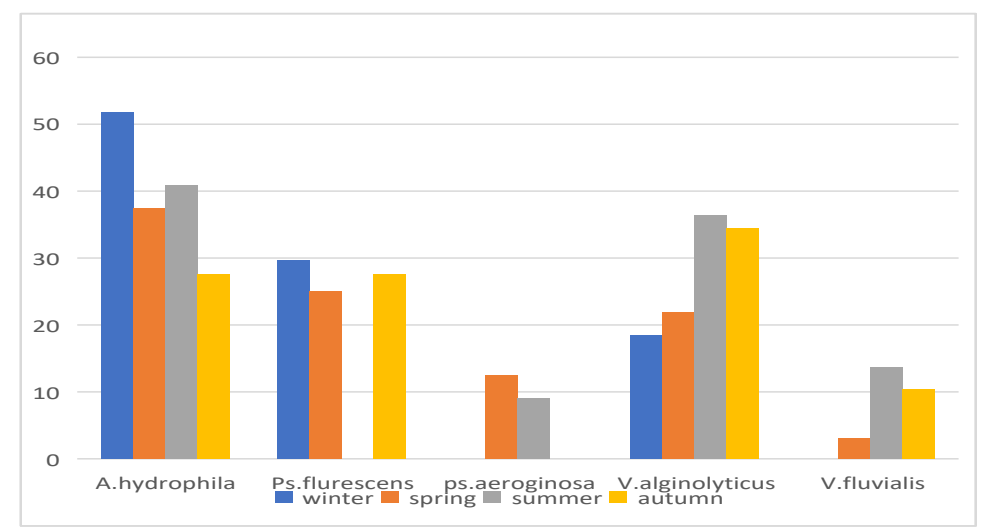

Figure (1) Seasonal prevalence of bacterial species in examined marine fishes

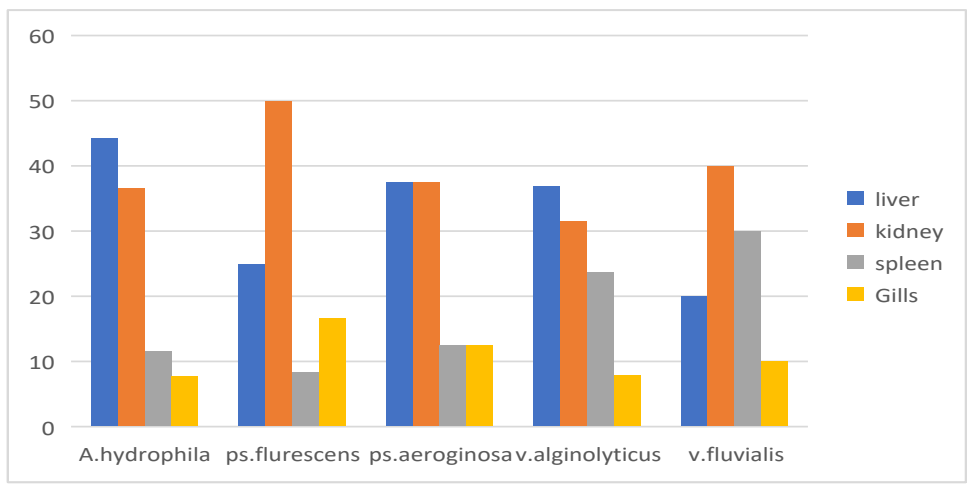

Figure (2) Incidence of bacterial species from examined organs of marine fishes

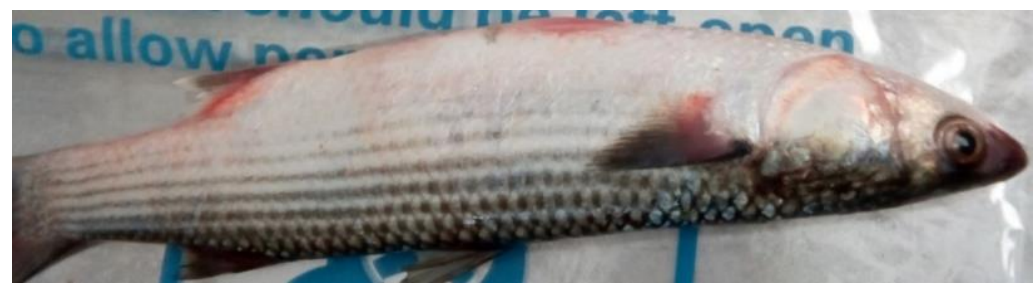

Photo (1) Diseased Capito with hemorrhage on body surface and on anal \& ventral Fines 


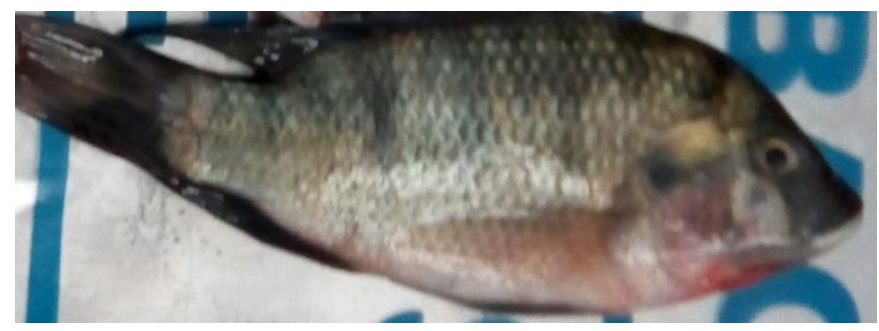

Photo (2) Diseased T. zilli showed hemorrhage around gill cover and on body surface

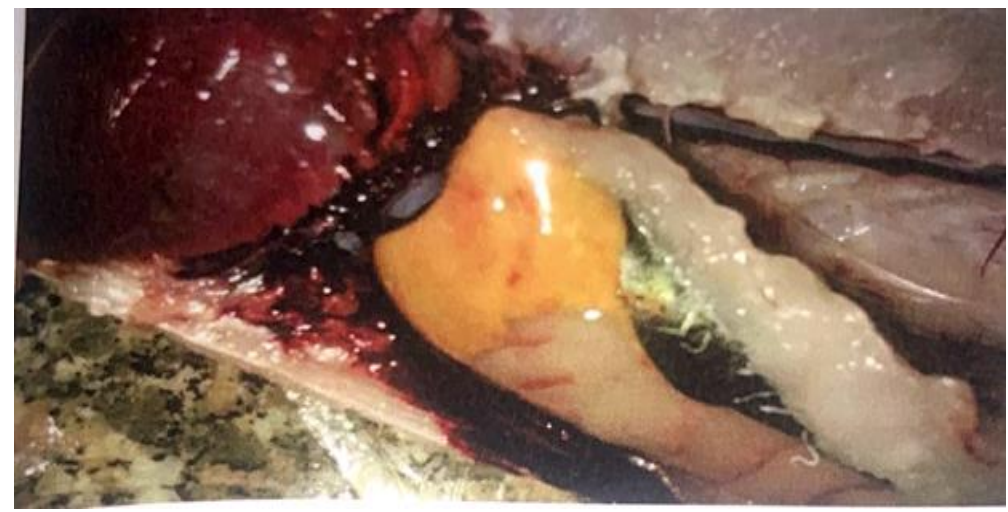

Photo (3) Diseased M. capito showed pale liver with hemorrhagic patches

\section{Discussion}

Fish are susceptible to a wide variety of bacterial pathogens. Many of these bacteria capable of causing disease are considered by some to be saprophytic in nature. These bacteria only become pathogen when fishes are physiologically unbalanced, nutritionally deficient, or there is other exophthalmia and some fish showed hemorrhages in eye, scales detachment and large stressor, i.e., poor water quality, overstocking, which allow opportunistic bacterial infection to proceed (Noga 2010).

Naturally infected marine fish (M.capito \& T.zilii) were clinically examined and the examination revealed the presence of darkness of external body surface, opacity of eye, increased in musous secretion, irregular hemorrhagic areas into many parts of the body, at base of fins, on gills cover, at the 
anal region, anal fin and caudal peduncle. There was abdominal distention observed in some fish and also fin \& tail rot. This result supported by previous studies which revealed by Megahed (2000), Ahmed (2004), Toranzo et al. (2005), El-Ashram and Azza (2006) and Moustafa et al. (2010) who recorded these signs beside anal inflammation as well as prolapsed. Regarding bacterial examination of some marine fish (M.capito \& T.zilli) present study detected that Tialpia spp. was the highest species infected with bacterial pathogens (55.30\%) and Mugil spp.was the lowest one $(44.70 \%)$ these may due to Mullet spp. was immunologically protected than Tilapia spp. This result agrees with El-Refaey (2013) who reported that regarding bacterial examination of fresh water fish, the study displayed that Tilapia spp was the highest spp. and the Mullets was the lowest one.

The present study showed that Aeromonas spp was isolated on Tryptic soya agar plate's colonies were creamy color, raised, rounded, shiny colonies. These results agree with Megahed (2000), Cipriano (2001), Ahmed (2004) and ElGendy (2007).

The naturally infected marine fish was recorded in the summer season (33.33\%), followed by the spring (24.24\%), then autumn (21.97\%), in contrast the lowest prevalence of infection recorded in winter $(20.46 \%)$. This variation may due to the change in water environment as increase water temperature which help bacteria proliferation and decrease oxygen dissolved in waste and this considered as stress factor on fish and made them susceptible for infection and these results supported by those reported by Company et al. (1999).

In regards to the seasonal prevalence of $A$. hydrophila the result pointed out that the highest prevalence was recorded in winter $(51.85 \%)$, followed by summer season $(40.91 \%)$, then spring $(37.5 \%)$, while the lowest recorded in autumn (27.59\%). Several researches investigated that Aeromonads prevail during summer season. This may attribute to the activity during high temperature due to stress condition that decrease fish immunity rendering them susceptible to diseases. These results are in concordance with those obtained by Hayes (2000). In the present study $V$. alginolyticus recorded (29\%) and are higher than those detected by Mustafa et al. (2010), and this higher prevalence of $\quad V$. alginolyticus indicate its importance in marine culture as 
supported by $\mathbf{Z h u}$ and Qian (2000).

The highest prevalence of $V$. fluvialis was recorded in summer $(13.64 \%)$, followed by autumn $(10.35 \%)$ while minimal in spring (3.13\%) and not isolated in winter.This result similar to Nam and Joh (2007) .

In regards to the total prevalence of Pseudomonas, the study recorded that $(24.24 \%)$ of infected fish were positive for Pseudomonas infection. These results were higher than that reported by Hussain (2002) and Mustafa et al. (2010).

In regards to the seasonal prevalence of $P$. fluorescens our results detected that the highest prevalence of $P$. fluorescens was recorded in winter (29.63\%), then autumn $(27.59 \%)$ and spring $(25 \%)$. While not recorded in summer season. This reveals that Ps. fluorescens has certain affinity to low temperature for propagation and spreading infection. This result agrees with Hoshino et al. (1997).

Concerning to the prevalence of bacterial isolates in various organs our investigation demonstrated that, prevalence of total bacterial isolates was $(37.84 \%)$ in kidney so it is the most predominant site for isolation of bacterial pathogens that causing septicemia as it is considered as one of the main hematobiotic organs of fish, followed by liver (36.36\%), then spleen $(15.91 \%)$ and finally gills $(9.85 \%)$. And this result goes along with

El-

\section{Refaey (2013).}

Results of antibiotic sensitivity revealed that $A$. hydrophila was highly sensitive to ciprofloxacin, nalidixic acid, oxytetracycline and also sensitive to amikacin. Intermediated to erythromycin but highly resistant to ampicillin, amoxicillin and linomycine and also rersistant to rifampicine and colistin sulfate. These result concur with $\boldsymbol{E l}$ Ashram and Azza (2006), On the other hand disagree with ELAdawy (2002) who showed that aeromonas was highly sensitive to amikcacin.

Results of antibiotic sensitivity revealed that Vibrio alginolyticus was sensitive to ciprofloxacin, oxytetracycline and rifampicine. While intermediate to colistin sulfate. Otherwise resistant to ampicillin, erythromycin \& lincomycine. These result assent with Wafeek et al. (2007), and with Enany et al. (2011) .

Results showed that antibiotic sensitivity revealed that $P$. fluorescens was highly sensitive to ciprofloxacin, rifampicine \& amikacin and also sensitive to oxytetracycline \& nalidixic acid. Intermediated to colistin sulfate. While resistant to erythromycin, ampicillin.These results accede with Ahmed (2004), El-Ashram 
and Azza (2006) and Enany et al. (2011) .

Results of antibiotic sensitivity revealed that $P$. aeruginosa was highly sensitive to ciprofloxacin \& amikacin. Intermediate for amokicillin \& colisten sulfate and resistant to nalidixic acid, rifampicine and highly resistant to ampicillin, oxytetracycline, erythromycin \& lincomycine. These result agree with Akinbowale et al. (2007) and Eissa et al. (2010).

\section{Conclusion}

It was concluded that the highest prevalence of bacterial isolates causing infection in marine fish were by A.hydrophila followed by $V$. alginolyticus, then $P$. fluorescens and the lowest prevalence was recorded for $P$. aeruginosa and $V$. fluvialis And the higher rate of infection recorded in summer season followed by the spring then autumn, in contrast the minimal incidence of infection were recorded in winter. Ciprofloxacin was considered the drug of choice for treatment and prevention of bacterial infection in marine fish either alone or combined with other antimicrobials.

\section{Refernces}

Ahmed, E. Z. A. (2004): Studies on disease problems in Mullet species in Dakhlia province. A thesis for degree of M. V. Sc fish diseases and management Dep. Faculty of Vet. Med. Mansoura University. Akinbowale, O. L.; Peng, H. and Barton, M. D. (2007): Antimicrobial resistance in bacteria isolated from aquaculture sources in Australia. J. Appl. Microbial., 100 (5): 1103-1113.

Brenner, D. J., Krieg, N. R., and Staley, J. T. (2005): Bergey's Manual of Systematic Bacteriology, 2 (c): 41-9

Buller, N. B. (2004): Bacteria from Fish and other Aquatic Animals: A Practical Identification Manual. CAB International publishing, Cambridge, Oxford shire, UK, 361pp.

Choopun, N., Louis, V., Haq, A. and Colwell, R. R. (2002): Simple Procedure for Rapid Identification of $V$. cholera from the Aquatic Environment. Applied \& Environment Micro. 68 (2), 995-998.

Cipriano, R. C. (2001): Aeromonas hydrophila and motile Aeromonad septicemias of fish. Fish disease leaflet 68 united states department of the interior fish and Wildlife Service Division of Fishery Research Washington, D. C. 20240.

Company, R., Sitijá Bobadilla, A., Pujalte, M. J., Garay, E., Alvarez-Pellitero, P., Pérez-Sánchex, J., (1999): Bacterialand parasitic pathogens in cultured common dentex, 
Dentex dentex L. J. Fish Dis. 22, 229-309.

Eissa, I. A. M.; Abo El Ghiet, E. N; Shaheen, A. A and Abbass, A. (2010):

Characterization of

Pseudomonas Species Isolated from Tilapia "Oreochromis niloticus" in Qaroun and WadiEl-Rayan Lakes, Egypt, Global Veterinaria, 5 (2): 116-121.

El Adawy, L. S. M. (2002): An investigation of bacterial pathogens infecting mullet (mugil capito) cultured in catfish. M. V. Sc. Thesis (microbiology), Fac. Vet. Med. Suez Canal University.

El-Ashram, A. M. M. and Azza, M. M. (2006): Acontribution on bacterial pathogins infecting mullet (Mugilcapito) cultured in fresh water farms in Sharkia governorate. "Egypt. J. Agric. Res., 84(1B).

El-Gendy, M. M. (2007): Epizootiological studies on some bacterial infections in marine fish. M. V. Sc (fish disease and mangments). Fac. Vet. Med. Suez Canal University.

El-Moghazy， D. F. (2004): Studies on pseudomonas septicemia in cultured Oreochromisniloticus fish. M. V. Sc., Thesis, Fish Disease and Management, Fac. Vet. Med. Suez Canal Univ.

El-Refaey, A. M. E. (2013): Studies on major bacterial diseases affecting fish; Tilapia Oreochromisniloticus, Catfish, Clariasgariepinusand mullets in Port Said, Egypt with special references to its pathological alterations, science journal:5(2):5-14.

Enany, M. EL.; Ibrahim H. M.; Abou El Atta, M. El.; ElAdawy, M. M. (2011): Bacteriological and histopathological studies on some bacterial pathogens causing diseases in cultured mugil capito fish in Ismailia governorate. SCVMJ, XVI (1).

FAO (Food and Agriculture Organization) (2004): Fish Statistics. Rome, Italy: FAO.

Hayes, J. (2000): Disease of fish spring 2000 Term project Oregon State University. MB52. Hoshino, T.; Ishizaki, K.; Sakamoto, T. \&Kumeta, H. (1997): Isolation of a Pseudomonas species from fish intestine that produces aprotease active at low temprature. Appl. Microbiol., 25:70-72.

Hudzicki, J. (2009). KirbyBauer disk diffusion susceptibility test protocol.

Hussain, R. A. (2002): Studies on some bacterial infections affecting certain marine fishes in the Arabian Gulf of Kingdom of Saudi ater. Bull Japanese Soc Sci Fishers 48: 1121-1127.

Megahed, A. A. (2000): Studies on some Gram-negative bacteria of fish Thisis, M, V. Sc., Microbiology, fac. Vet. Suez 
Canal University.

Moustafa ,M.; Laila , A. M; mahmoud, M. A ;soliman, W. S, and EL-gendy, M. Y. (2010): Bacterial infections affecting marine fishes in Egypt, Journal of American Science :6(12):1314- 1324.

Nam, I. Y, and Joh, K. (2007): Rapid detection of virulence Factors of Aeromonas isolated from a Trout farm by Hexaplex PCR, j. of Mic, 45 94): 297-304. Noga, E. J. (2010): Fish Disease: Diagnosis and Treatment. Ames, IA: Iowa State University Press.

Ottaviani, D.; Masini, L. and Bacchiocchi, S. (2003): He,olysin, Protease, and EPS Producing Pathogenic Aeromonas hydrophila Strain An4 Shows Antibacterial Activity against Marine Bacterial Fish Pathogens, Journal of Marine Biology, 2010, Article ID 563205, 9 pages.

Salah, M.; Wael, G.; Mounir, M., and Salem, S. (2012): Bacteriological and Histopathological Studies on Enterobacteriacea in Nile
Tilapia Oreochromis Niloticus. J. Pharm. Biomed. Sci., 2 (7) 94-104.

Toranzo, A. E., Magari os, B. \&Romalde, J. L. (2005): A review of the main bacterial fish diseases in mariculture systems. Aquaculture 246: 37-61.

Wafeek, M.; Abou El Atta, M. and Ebrahem, G. (2007): Heavy metals and bacterial distribution in different organs of Grey mullet (Mugilcephalus) cultured in different environmental conditions. Egypt J. Aquat. Biolo\&Fish, Vol. 11, No3; 1125-1144.

Wedekind, C.; Gessner, M. O.; Vazquez, F., Maerki, M.; and Steiner, D. (2010): Elevated resource availability sufficient to turn opportunistic into virulent fish pathogens. Ecology, 91(5): 1251-1256.

Zhu, J. Q., \& Qian, W. P. (2000): Cause and Countermeasure of Genetical Characterization Decline in Marine Cultural Species [J]. Journal of Ningbo University (Natural science \& Engineering Edition), 2. 


\section{انتثار و مدى قابلية المضادات الحيوية للبكتريا الممرضة في أسمالك الثبار

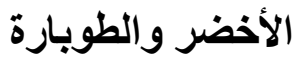

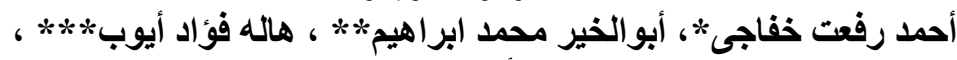

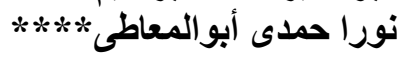

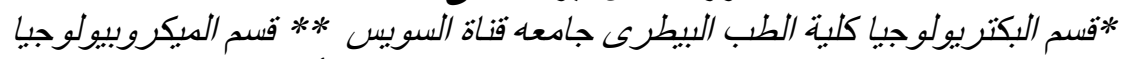

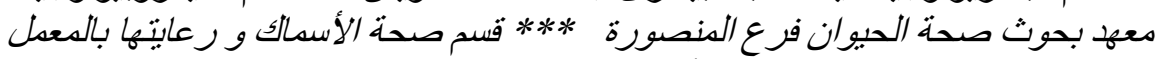

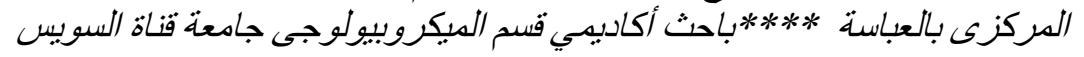

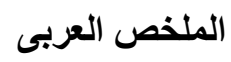

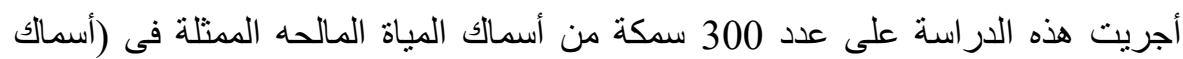

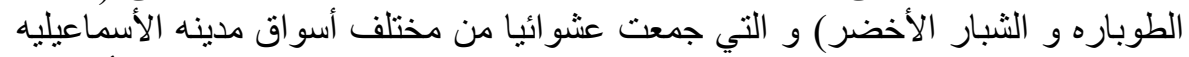

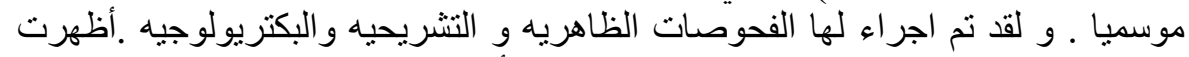

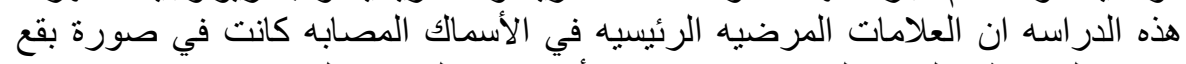

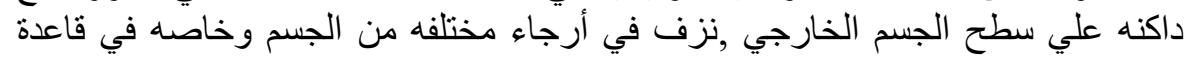

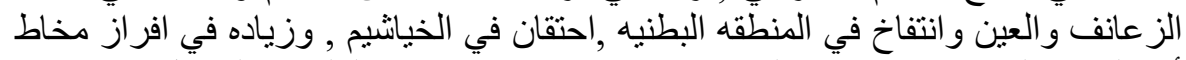

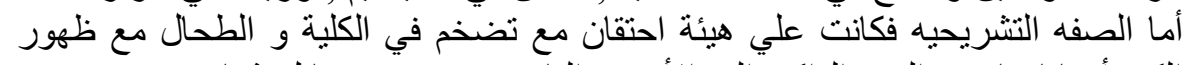

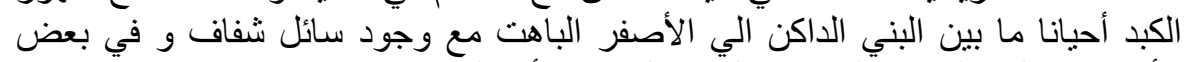

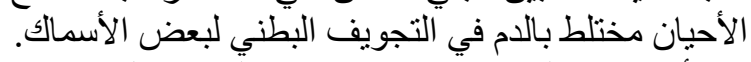

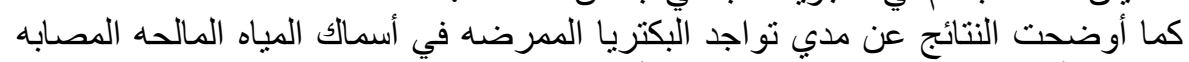

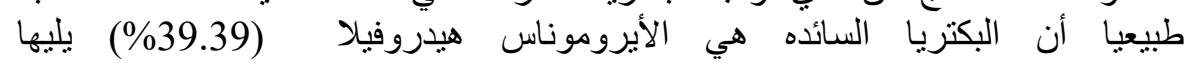

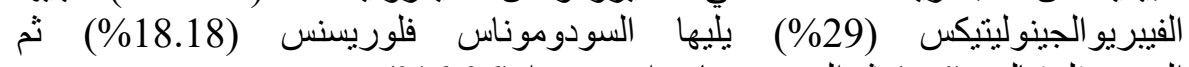

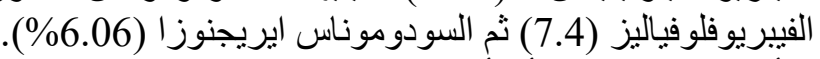

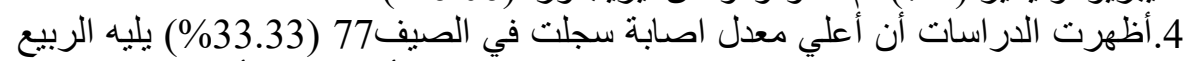

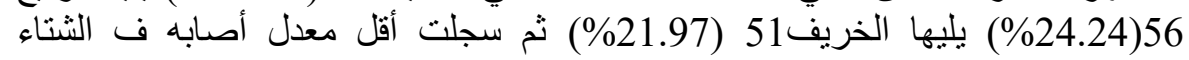
. $\% 20.46) 47$

...أظهرت النتائج أن معدل الأصابه بميكروب الأيروموناس هيدروفيلا كانت عالية في

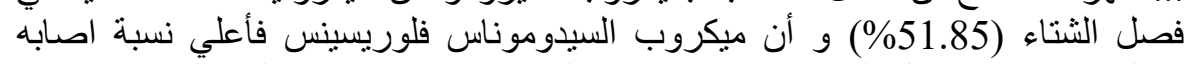

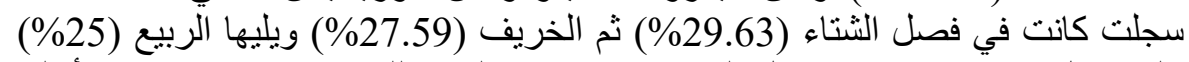

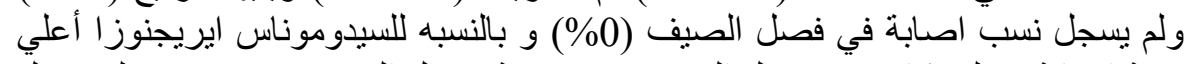

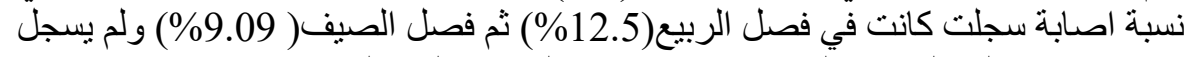

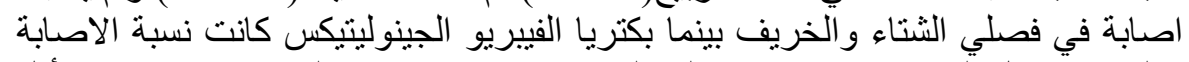

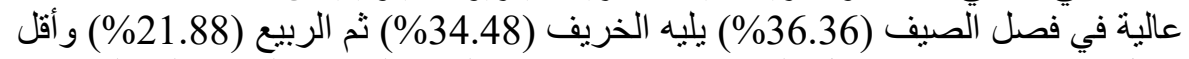

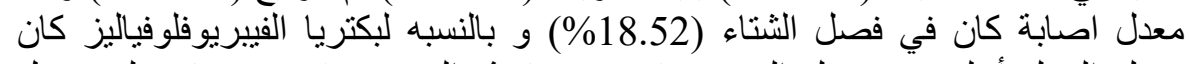

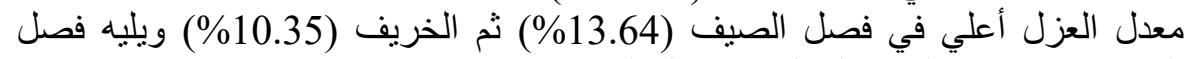
الربيع (3.13\%) ولم يتم العزل في في فصل الثل الثناء.

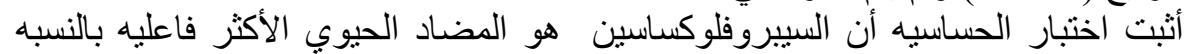

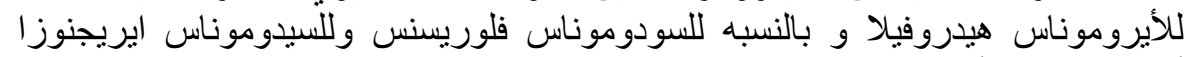

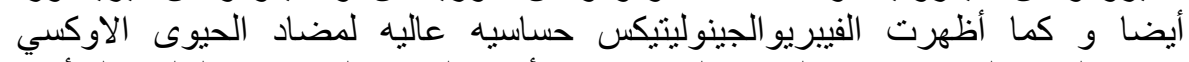

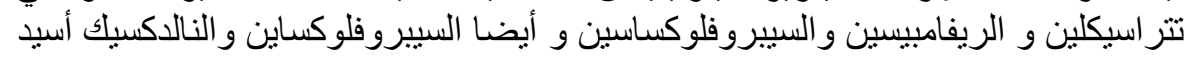
بالنسبه للفيبريو فلوفين الريزيز 